\title{
sobre: Contiendas en torno al canon. Las historias de la literatura argentina posdictadura, de Guadalupe Maradei.
}

\author{
Buenos Aires: Corregidor, 2020.
}

\author{
ANALÍA GERBAUDO Universidad Nacional del Litoral - CONICET, Argentina \\ ORCID 0000-0001-9969-8004 \\ agerbaudo@fhuc.unl.edu.ar/analia.gerbaudo@conicet.gov.ar
}

\section{Ese juego de in-dóciles bucles y de envíos...}

Ya desde el arranque, la cosa no promete paz: pensar la construcción del canon transida por las «contiendas» supone, como bien observa Jorge Panesi en el texto que funciona como contratapa a este libro de Guadalupe Maradei, apartarse de la posición que lo concibe como una «sucesión pacífica de altas y bajas» para asumirlo «como un necesario conflicto, como una lucha». En dos escuetos párrafos, su envío agrega a las controversiales definiciones de posdictadura sobre las que Maradei se concentra, otra más: se trata de «un momento turbador de la historia nacional, heredero de una violencia y de un trauma». Y por si algo le faltara, pronuncia con su usual galanura una suerte de veredicto: lo que Maradei construye es «un exacto relato de un momento de la crítica literaria argentina» y, a la vez, una historia de «la historiografía (literaria o no)» y sus «operaciones», un término que no emplea en esta oportunidad pero que le tomo prestado de aquel texto antológico de 1998 que daba letra al título del libro que lo contenía. En «Las operaciones de la crítica: el largo aliento», Panesi no ocultaba su deuda con Michel Foucault ni con Pierre Bourdieu, ese mal querido de los estudios literarios en Argentina a quien sin embargo entonces retomaba para pensar «los campos literarios» como terrenos contenciosos. Aquel artículo señero dejó su huella, claro está, en ella, una de sus herederas, la autora de este libro necesario.

En su relato sobre las historias de la literatura nacional escritas durante la posdictadura, Maradei señala una relación entre compulsiva y sintomática entre crisis y escritura: pareciera que la necesidad de volver a contar el cuento sobre nuestros «orígenes» y derroteros se activara en tiempos turbulentos. En esa línea destaca que «la edición original del primer tomo publicado de la Historia social de la literatura argentina, dirigida por David Viñas, empezó a gestarse a mediados de los 80's» (13) y que la Historia crítica de la literatura argentina dirigida por Noé Jitrik arrancó en 1999: se trata, entonces, de proyectos pensados y/o iniciados ya sea después de la «"larga noche" de la última dictadura militar», ya sea durante «la "intemperie” de la década de 1990» (13). Todo parecía indicar que el hasta entonces «vilipendiado género de la historiografía literaria»

Para citar este artículo: Gerbaudo, A. (2020). Sobre: Contiendas en torno al canon. Las historias de la literatura argentina posdictadura, de Guadalupe Maradei. El taco en la brea, 12 (junio-noviembre). Santa Fe, Argentina: UNL. eoo19 DOI: 10.14409/tb.vii12.9697 
estaba desplazándose del lugar menor al que había intentado confinárselo: como los cuentos sobre orígenes y derroteros que estas historiografías construyen en más o menos clara expresión de una "memoria literaria en disputa», esta emergencia así como el género de borde de este texto de Maradei se inscriben en un espacio de enfrentamiento por la definición de los modos de construir los estudios literarios desde Argentina.

En Santa Fe, mi ciudad, un grupo de diseñadores de ropa inventaron una marca cuyo nombre viene para la ocasión: Haceme un espacio. Lo que el cuento que Maradei cuenta deja entrever es un movimiento que va en ese sentido: frente a las narraciones con fantasías totalizadoras y monológicas, su investigación reconstruye parte de las batallas sostenidas para legitimar un género que aprovecha una "grieta» en el sentido heurísticamente potente que supo darle al término Eduardo Rinesi en la teoría política que construyó, entre Shakespeare y Derrida, antes de que los sectores más rancios de la derecha intentaran degradarlo junto con las acciones que acarreara. El cuento que Maradei cuenta (y que se reclama como tal desde el acertado epígrafe de Bertolt Brecht que ubica a las historias de la literatura en el género de la literatura policial) envía a los de David Viñas, Noé Jitrik, Nicolás Rosa y Martín Prieto. Todos, obsesionados por la reinvención del género «historia de la literatura (nacional)» vía la palabra literaria resuelta en forma de ensayo:

Nuevas apreciaciones de lo ya conocido, hallazgos provenientes de la exhumación e, incluso, de la creación de archivos, la atención a prácticas y a lenguajes antes inexistentes o desdeñados, logran articularse con nuevas formas de periodización, intervenciones sobre el canon y operaciones críticas en las que las apropiaciones de la teoría y la colisión de discursos críticos cobran protagonismo, del mismo modo en que lo hace aquello que Nicolás Rosa llamó una bella escritura. (13-14)

Me apresuro en aclararlo: si bien tengo fantasías de Pierre Menard, no voy a copiar ni a describir el libro completo (ganas no me faltan, aunque para eso, mejor la clase donde puedo dar rienda suelta a mi deseo). En esta oportunidad, me detengo en algunas de sus decisiones más riesgosas porque encuentro en ellas, como en cada decisión de este tipo tomada en cada investigación, el punto en que el campo se enriquece: acogerse en la seguridad de lo autorizado no pareciera impulsar el avance sobre «lo que no se sabe» (todavía), como bien aprendimos de Miguel Dalmaroni a través de su indispensable best-seller La investigación literaria: problemas iniciales de una práctica (adjetivación necesaria para un libro que democratizó los protocolos hasta entonces implícitos en las morales de la investigación en Argentina: esos que nunca antes nadie había transparentado ni enseñado a pesar de que regían la evaluación de los proyectos, un género que operaba como las puertas de la ley y a su "conocedor», como el guardián en el célebre cuento de Kafka).

La primera de esas decisiones: Maradei observa en las citadas historias de Viñas y de Jitrik y en la Breve historia de la literatura argentina de Martín Prieto (2006) una relación «incómoda» que, si bien por un lado supone una reflexión tramitada desde los campos editorial, académico y literario alrededor de "un tipo de producción cultural de un determinado Estado-nación", por el otro, deja entrever una distancia «tanto de la categoría como del modo de organización política así identificado» (2020:14). Su hipótesis es inquietante y se apoya en argumentos convincentes. Entre el Rafael Spregelburd de Apátrida, doscientos años y unos meses y el Ricardo Piglia de 
La Argentina en pedazos pero, sobre todo, en deuda con Panesi, lector de Contorno, Maradei hace sobresalir el gesto crítico y sintomático traducido en más de una historia, en más de un cuento y, en particular, en más de una construcción heterodoxa. A contrapelo de los «nacionalismos metodológicos» de afanes totalizadores, las historias que la ocupan se quieren fragmentarias, posicionadas, no-neutras, literarias:

Lejos del ímpetu positivista y nacionalista de Rojas pero también del acriticismo de Arrieta y de la esperanza de democratización del CEAL, las nuevas historias parecen haberse liberado del mandato de tributar a la construcción de una cultura nacional.

En ese movimiento aporético, las nuevas historias delinearon su genealogía como dignas sucesoras de la crítica contornista que, varias décadas antes de que los estudios subalternos pensaran el estatismo como la ideología que autoriza que los valores dominantes del Estado determinen el criterio de qué puede considerarse histórico (Ruha, 2002) y de que Josefina Ludmer (2010) articulara como máquina de lectura los tonos antinacionales en las literaturas latinoamericanas contemporáneas, ya había lanzado su programa crítico de lectura contra oficial de la literatura argentina. Valgan como evidencia de esta filiación los posicionamientos críticos del proyecto historiográfico de David Viñas en torno al proyecto político de la oligarquía liberal con su corte de escritores adherentes, por un lado, y las producciones literarias que, como el grotesco criollo, mostraron el reverso del progreso y la modernización en términos de fracaso; la preocupación de la Historia crítica de la literatura argentina de Noé Jitrik por marcar las fundaciones múltiples de la literatura argentina y su relación inestable con los proyectos estatales así como el trauma del terrorismo de Estado que subsiste en los intersticios de una lengua culpable; $\mathrm{y}$ la convicción de Martín Prieto, en su Breve historia de la literatura argentina, de «desestimar cualquier ilusión de convertir esta historia en una suerte de 'biografía nacional' al uso» (Prieto, 2006:9) junto con la irreverencia de abrir el relato historiográfico con un «Capítulo-1» que parte desde principios del siglo XVI, es decir, siglos antes de la constitución del Estado-nación, para pensar la relación entre lenguas originales, exterminio, diccionarios y crónicas producidas sobre el territorio que más de tres siglos después ocuparía la República Argentina. (14-15)

La segunda decisión va en serie con la anterior: un par de páginas más adelante, Maradei resalta el carácter dinámico de este movimiento en la grieta abierta entre los géneros del campo de los estudios literarios: su defensa del que estudia y ensaya mientras escribe los resultados de su investigación se sostiene en su convicción respecto de su importancia ética y política. De este modo, sin dudar respecto de los resultados por-venir, se expide sobre la Historia feminista de la literatura argentina coordinada por Nora Domínguez, en preparación. Es justamente a partir de sus avances que esgrime un comentario respecto de la "potencia crítica de los relatos historiográficos para capturar y tejer retazos de sentido a partir de una literatura que, lejos del conformismo y del discurso oficial, alimenta y se alimenta de la disidencia» (17). Así, el libro se abre a lo por-venir, entre la promesa y la advertencia, como alertando: «atención que esto recién empieza».

La tercera decisión: para construir su cuento, Maradei se vale de otros, además de los ya citados. Por esta estrategia su investigación puede ser puesta en serie con otras concluidas y en curso destinadas a reconstruir tanto procesos de institucionalización, de configuración del gusto, dinámicas del campo editorial como un nuevo relato sobre la historiografía de la literatura nacional: 
todas recurren a la entrevista para construir sus datos (cf. Szpilbarg; Benzecry; Santomero; Santomero y Ramírez; Santomero y otros; Prieto, 2020). Maradei se pronuncia sobre la relevancia heurística del recurso: la restitución de la voz a quienes narran los cuentos que interpreta permite complejizar la lectura de las tensiones constitutivas del campo que son las que, a la vez, le confieren vitalidad y dinamismo. Se trata de un recurso indeclinable de su «análisis»:

Con el correr del tiempo, a medida que avanzaba la investigación, fui arriesgando lecturas sobre ese corpus abierto e incompleto de colecciones de historiografía literaria en proceso de publicación, apuntalando el análisis y cotejo de textos críticos y teóricos con la recolección de decenas de testimonios de los/as críticos/as que dirigieron las colecciones, coordinaron los tomos o colaboraron en el proceso. (15)

La cuarta: vuelve a usar y a diseminar el complejo término «posdictadura». Sus precisiones metodológicas así como el deslinde de algunos de los «equívocos» alrededor de sus usos convierten a este texto en referencia indispensable para las investigaciones por-venir que lo empleen. Me atrevo a agregar que su categoría «historias de la literatura argentina posdictadura» (22) funciona también como reinvención, entre el don y la deuda, de la hipótesis que Panesi había esbozado en "Pasiones de la historia» (1999): la tesis sobre el pathos hacia la historia de la literatura que se dejaba entrever, no sin resistencias de campo, en la crítica argentina desde Contorno en adelante, es revisada por Maradei veinte años después, con nuevos datos, desde una nueva configuración política y desde un ensamblaje teórico que pone en contigüidad productiva a Ana Pizarro, Judith Butler, Dominick LaCapra y Michel Foucault, entre otros. Su texto despliega una conjetura poderosa alrededor de la pregunta por el tipo particular de pulsión que estas historias dejan entrever: se trataría de «una pulsión particular hacia su objeto, hacia sí mismas y hacia el sujeto al que destinan su escritura crítica» (22). Al respecto, me inclino a pensar que es porque establece a la «posdictadura como umbral de investigación» que Maradei puede desentrañar la complejidad de elementos que se intersectan en el proceso de institucionalización de los estudios literarios en Argentina: en su lectura del volverse auto-bio-grafía e historia política de la crítica como una reacción contra la línea «tradicionalista e impresionista de la cultura dictatorial» y contra «el cientificismo estructuralista que proponía la neutralidad del modelo de análisis» sitúa el «viraje» que encuentra en las «nuevas historias de la literatura argentina» que estudia (27) y cuyo movimiento prolonga mientras escribe la suya y envía a otras por-venir.

La quinta decisión: Maradei arriesga su lectura respecto de cómo estas historias componen sus periodizaciones e intervienen sobre el canon mientras, a partir de una difícil operación, sitúa esas «intervenciones» en el escenario compuesto por posiciones institucionales y «posicionamientos políticos manifiestos de los críticos y editores»: se vale para ello del análisis de algunos de los «intensos debates» alrededor del «proceso de producción de cada proyecto editorial en particular» (20).

Imposible no estar expectante, luego de su lectura, de la historia por-venir a la que su libro envía. Imposible no temblar ante cada decisión de enseñanza y de investigación que involucre algunos de estos cuentos, básicamente, porque de aquí en más estos relatos fundantes y necesarios, estimulantes por sus acuerdos y también por sus desacuerdos, solicitan ser leídos por este otro: el que Maradei compone mientras los trae a su escritura. He aquí su fantasía que, traducida en texto, ya produce efectos de campo (entre otros, esta reseña, aquí y ahora): 
No imaginé una reconstrucción exhaustiva ni intenté establecer jerarquías o juicios de valor respecto de los materiales analizados sino historiar el carácter de intervención político-cultural de las prácticas de periodización crítica y los discursos que los sujetos críticos formulan sobre dichas prácticas (recogidos mediante entrevistas), a partir de núcleos problemáticos que permiten indagar el estatuto actual de la literatura y de la crítica en el campo material de la cultura argentina desde 1983 hasta el presente. (20)

\section{Referencias}

Benzecry, C. (2012). El fanático de la ópera. Etnografía de una obsesión. Buenos Aires: Siglo XXI.

Dalmaroni, M. (2009). La investigación literaria. Problemas iniciales de una práctica. Santa Fe: UNL.

Panesi, J. (1998). Las operaciones de la crítica: el largo aliento. En Alberto Giordano y María Celia Vázquez, compiladores. Las operaciones de la crítica. Rosario: Beatriz Viterbo, 9-22.

Panesi, J. (1999). Pasiones de la historia. Filología, (32), 121-128.

Prieto, M. (2006). Breve historia de la literatura argentina. Buenos Aires: Taurus.

Prieto, M. (2020). Juan José Saer en la literatura argentina. Tesis doctoral. Rosario: UNR.

Santomero, L. (2019). Apuntes sobre la institucionalización de los estudios lingüísticos en la universidad pública de la posdictadura argentina (UNL, 1991-2003). VII Coloquio de Avances de Investigaciones del CEDINTEL. Santa Fe: CEDINTEL/FHUC.

Santomero, L. y Ramírez, C. (2020). Letras y enseñanza. Notas sobre institucionalización y resistencias en la posdictadura argentina. Babedec, (18). https://revista.badebec.org/index.php/badebec/article/ view/450/406

Santomero, L. y otros (2019). Los institutos de formación docente y la institucionalización de los estudios literarios, lingüísticos y semióticos (Argentina, 1958-2015). X Congreso Nacional de Didáctica de la Lengua y la Literatura. Buenos Aires: UNSM.

Szpilbarg, D. (2019). Cartografía argentina de la edición mundializada: modos de hacery pensar el libro en el siglo XXI. Temperley: Tren en movimiento. 